\title{
VERNAKULARITAS ARSITEKTUR PENINGGALAN PERADABAN ISLAM
}

\author{
Anisa \\ Jurusan Arsitektur, Fakultas Teknik, Universitas Muhammadiyah Jakarta, \\ Jl Cempaka Putih Tengah 27 Jakarta Pusat 10510 \\ *anisa@umj.ac.id
}

Diterima: 22-07-2021 Direview : 07-08-2021 Direvisi : 10-08-2021 Disetujui: 15-08-2021

ABSTRAK. Peninggalan dari sebuah peradaban dapat dilihat dari karya yang ditinggalkan. Arsitektur merupakan salah satu wujud karya yang dapat digunakan untuk melihat dan menelusuri peninggalan dari sebuah peradaban. Peninggalan peradaban di satu wilayah dengan wilayah lain akan dipengaruhi oleh kondisi lingkungan setempat. Hal inilah latar belakang pentingnya dilakukan penelitian berkaitan dengan vernakularitas arsitektur. Penelitian ini merupakan penelitian yang bertujuan untuk mengidentifikasi, mendeskripsikan dan memahami vernakularitas peninggalan peradaban Islam. Metode yang digunakan pada penelitian ini adalah metode deskriptif kualitatif dengan pengambilan data dilakukan secara purposif sampling. Alat analisis pada penelitian ini adalah aspek vernakularitas yang dikemukakan oleh Mentayani (2017). Aspek vernakularitas dapat dilihat dari 3 hal yaitu aspek teknis, aspek budaya, dan aspek lingkungan yang ketiganya bisa dibahas secara bersamaan karena saling terkait pada ranah unsur dan abstrak. Kesimpulan yang didapatkan dari penelitian ini adalah : (1) vernakularitas pada arsitektur peradaban Islam dapat dilihat pada bentuk massa dan denah bangunan, yang tidak selalu mengikuti bentuk awal (tipologi) peninggalan peradaban Islam yaitu hypostyle; (2) vernakularitas ditunjukkan pada penggunaan material setempat dengan teknologi setempat, misalnya di Afrika Barat menggunakan bata tanah liat yang dikeringkan tanpa dibakar dan penguat dinding dari batang kayu.

Kata kunci:vernakularitas, arsitektur, peninggalan peradaban Islam

ABSTRACT. The legacy of a civilization can be seen from work left behind. Architecture is a form of work that can be used to view and trace the relics of a civilization. Local environmental conditions will influence the legacy of civilization from one region to another. This statement is the background of the importance of conducting research related to architectural vernacular. This research aims to identify, describe, and understand the vernacular of Islamic civilization heritage. The method used in this study is a qualitative descriptive method with data collection carried out by purposive sampling. The analytical tool in this study is the aspect vernacularly proposed by Mentayani (2017). Aspects of vernacular can be seen from three things, namely technical aspects, cultural aspects, and environmental aspects, all three of which can be discussed simultaneously because they are interrelated in the elemental and abstract realms. The conclusions of this study are as follow: vernacular in Islamic civilization architecture can be seen in the shape of the mass, and building plans, which do not always follow the initial form (typology) of Islamic civilization heritage, namely hypostyle; vernacular is shown in the use of local materials with local technology, for example in West Africa using clay bricks that are dried without being burned and wall reinforcement from logs.

Keywords: vernacularity, architecture, heritage of Islamic civilization

\section{PENDAHULUAN}

Istilah Vernakular banyak digunakan untuk menyebutkan arsitektur yang merupakan hasil karya setempat, dengan material setempat dan didesain sesuai kebutuhan masyarakat. Masner dalam (Saraswati, 2008) menyatakan bahwa bangunan yang vernakular adalah bangunan yang didirikan dari material setempat di lokasi tersebut. Salah satu ciri bangunan vernakular adalah kebutuhan manusia yang berpengaruh terhadap bentuk dan strukturnya.
Arsitektur vernakular dapat dilihat pada berbagai tipe bangunan. Contoh arsitektur vernakular yang ada di Indonesia adalah rumah tradisional. Selain rumah tradisional, arsitektur vernakular juga dapat dilihat pada penataan permukiman yang sesuai dengan kebutuhan masyarakatnya seperti Kali Code.

Vernakularitas pada arsitektur bisa dilihat pada bangunan, maupun kawasan. Vernakularitas juga dapat ditelusuri pada bangunan hunian 
dan beberapa tipe bangunan lain, termasuk di dalamnya bangunan peribadatan.

Bangunan peribadatan, salah satunya masjid merupakan bangunan yang menarik secara arsitektural karena dengan fungsi yang sama masjid bisa berbeda bentuknya. Dapat dilihat masjid yang ada di berbagai daerah mempunyai bentuk yang berbeda. Bentuk yang berbeda tersebut ada kemungkinan disesuaikan dengan kondisi lingkungan dan kebutuhan masyarakatnya.

Arsitektur berkaitan dengan berbagai bidang ilmu antara lain kebudayaan dan peradaban. Peradaban digunakan untuk menyebut bagianbagian kebudayaan yang halus dan indah. Peradaban dipakai juga untuk menyebut kebudayaan yang mempunyai sistem teknologi, seni bangunan, seni rupa, sistem kenegaraan dan ilmu pengetahuan yang maju dan kompleks. (Nasution, 2013)

Peradaban bisa dilihat pada peninggalan arsitekturnya. Hal inilah yang mendasari pentingnya dilakukan penelitian berkaitan dengan vernakularitas pada bangunan masjid. Pada perkembangannya, ada bangunanbangunan lain yang dibangun di sekitar masjid dan berkaitan dengan masjid. Penelitian ini kemudian diberi judul yang lebih umum yaitu arsitektur peninggalan peradaban Islam. Peninggalan peradaban Islam tersebar di dunia, tidak hanya di jazirah Arab saja tetapi juga di benua lain bahkan sampai di Indonesia. Tulisan ini merupakan bagian dari penelitian yang dilakukan, dengan mengambil studi kasus arsitektur peninggalan peradaban Islam yang ada di Afrika. Afrika diambil sebagai salah satu studi kasus karena keunikan bangunan yang masih dapat ditemukan. Bangunan-bangunan tersebut terlihat berbeda dengan peninggalan peradaban Islam di tempat lain, walaupun secara fungsi sama.

Fokus pembahasan pada tulisan ini dibatasi peninggalan arsitektur di Afrika Barat yang terbagi menjadi 4 kawasan utama yaitu Sahara, Schel, Shavannah, dan hutan tropis. Islam masuk ke Afrika Barat melalui jalur perdagangan dari Afrika Utara terutama setelah Roma dan Bisantin runtuh. Perdagangan sudah ada sejak zaman Romawi dan Bisantin.

Publikasi penelitian berkaitan dengan arsitektur vernakular dan vernakularitas sudah ditelusuri pada beberapa Jurnal antara lain tulisan Saraswati (2008), Anisa \& Nur'aini (2020), Wulandari et al. (2018), Sinaga (2017) dan berbagai penelitian lain. Saraswati memaparkan vernakularitas pada bangunan Los, Anisa dan Nur'aini memaparkan vernakularitas pada rumah kilungan, Wulandari mengkaji ekspresi bentuk Arsitektur Masjid Bengkulu, dan Sinaga mengkaji ekspresi vernakular minangkabau pada Masjid Gantiang. Dasar teori mengenai aspek vernakularitas didapatkan dari penelitian (Mentayani et al., 2017) yang berjudul Menggali Makna Arsitektur Vernakular: Ranah, Unsur, dan Aspek-Aspek Vernakularitas.

\section{METODE PENELITIAN}

Penelitian tentang vernakularitas ini menggunakan metode deskriptif kualitatif dengan mengambil studi kasus peninggalan peradaban Islam di Afrika. Metode deskriptif digunakan untuk mendapatkan gambaran secara utuh terhadap suatu permasalahan. Dengan metode deskripsi, diharapkan tujuan penelitian dapat tercapai. Metode kualitatif digunakan dalam proses pengambilan data dan analisis. Data dikumpulkan melalui sumber sekunder karena kondisi pandemi. Pengumpulan data menggunakan purposive sampling dengan menelusuri literatur mengenai peninggalan peradaban Islam yang ada di Afrika.

Materi penelitian berupa kondisi fisik dan kondisi non fisik bangunan peninggalan peradaban Islam di Afrika. Termasuk kondisi nonfisik adalah data berkaitan dengan iklim setempat dan kondisi geografisnya.

Tahapan penelitian yang dilakukan secara umum meliputi 4 tahap. Pertama, melakukan studi literatur untuk mendapatkan teori tentang vernakular secara umum dan untuk mendapatkan data awal berkaitan dengan fenomena yang akan diteliti. Kedua, melakukan identifikasi berkaitan dengan teori yang akan digunakan sebagai alat analisis. Ketiga, melakukan identifikasi dan deskripsi terhadap peninggalan arsitektur peradaban Islam di Afrika menggunakan alat analisis yang ditentukan. Tahap kelima adalah melakukan penafsiran dan penarikan kesimpulan.

Alat analisis yang digunakan berupa rangkaian teori yang dipaparkan oleh (Mentayani et al., 2017) berkaitan dengan ranah, unsur dan aspek vernakularitas. Ada tiga aspek yang digunakan yaitu aspek teknis, aspek budaya dan aspek lingkungan. 


\section{HASIL DAN PEMBAHASAN}

\section{Arsitektur Vernakular dan Vernakularitas}

Bernard Rudofsky pada tahun 1964 dalam pameran bertema Architecture without Architect memperkenalkan istilah arsitektur vernakular sebagai arsitektur lokal yang umumnya berupa hunian yang ditemukannya di berbagai tempat di dunia (Artiningrum \& Sukmajati, 2017).

Sedangkan menurut Sumintardja (1981), arsitektur sebagai hasil karya manusia dipengaruhi oleh keadaan geografis, geologis dan iklim. Arsitektur akan merespon dimana didirikan. Arsitektur juga akan memberi respon terhadap iklim yang ada ditempat tersebut.

Material lokal dan teknik pembangunan secara lokal juga menjadi salah satu ciri arsitektur vernakular. Hal ini terjadi karena arsitektur vernakular tumbuh dan berkembang dari arsitektur rakyat. Arsitektur vernakular awalnya lahir dari masyarakat etnik dan berdasarkan pada tradisi etnik. Pendapat diatas diperkuat dengan paparan Turan bahwa arsitektur vernakular dibangun berdasarkan pengalaman masyarakat setempat, menggunakan teknik dan material lokal serta merupakan jawaban atas kondisi lingkungan tempat bangunan tersebut berada (Turan dalam Tarigan, 2016).

Rapoport mengungkapkan bahwa arsitektur vernakular dapat diartikan juga sebagai arsitektur yang lahir dari komunitas tertentu yang dibuat oleh dan untuk masyarakat atau kebudayaan tertentu (Rengkung, 2011).

Merujuk pada beberapa definisi di atas bahwa arsitektur vernakular tidak hanya dapat ditemukan pada bangunan-bangunan tradisional pada jaman dahulu saja. Arsitektur vernakular akan ada di sepanjang masa dengan definisi bahwa arsitektur vernakular berkaitan dengan lokalitas, material lokal, teknik pembangunan lokal, untuk memenuhi kebutuhan masyarakat setempat, dan merespon terhadap kondisi setempat.

Arsitektur vernakular tidak hanya dapat diidentifikasi pada tata ruang saja. Arsitektur vernakular juga dapat dilihat antara lain pada proporsi. Proporsi pada karya arsitektur vernakular juga sesuatu yang khas karena bisa ditentukan dari sebuah dasar ukuran bagian tertentu pada bangunan vernakular misalnya proporsi menggunakan proporsi pada tubuh manusia. (Sani, dkk. 2015).
Arsitektur vernakular juga dapat ditemukan pada arsitektur tradisional dengan struktur masyarakat yang homogen. Pada penelitian Artiningrum \& Sukmajati (2017) ditemukan bahwa pada Kampung nelayan Kamal Muara ditemukan arsitektur vernakular sebagai permukiman yang diprakarsai oleh masyarakat sendiri dengan material dan teknologi setempat dan dibangun dengan kaidah budaya asal.

Dapat disimpulkan bahwa arsitektur vernakular adalah arsitektur yang memiliki sifat kelokalan atau lokalitas. Arsitektur vernakular juga bermakna sebagai arsitektur yang menyesuaikan iklim lokal, menggunakan teknik dan material lokal, dipengaruhi aspek sosial, budaya, dan ekonomi masyarakat setempat. Arsitektur vernakular juga dapat diungkapkan sebagai kesatuan antara bentukan fisik dan kandungan makna abstrak yang terwujud melalui teknis, dilandasi budaya dan dipengaruhi oleh lingkungan (Mentayani, et al, 2017).

Mentayani et al. (2017) memaparkan ada 3 aspek vernakularitas yang berada pada sisi ranah maupun unsur. Ketiga aspek tersebut adalah aspek teknis, aspek budaya, dan aspek lingkungan. Aspek teknis merupakan hal-hal yang dapat diamati secara fisik, misalnya struktur, konstruksi, material dan bahan serta proses pengerjaanya. Aspek budaya berkaitan dengan semangat dan jiwa yang terkadung di dalam fisik bangunannya. Sedangkan aspek lingkungan berkaitan dengan kondisi lingkungan dimana bangunan itu berada. Lingkungan dan budaya saling berkaitan membentuk arsitektur vernakular.

Tiga aspek pembentuk vernakularitas yang ada dalam ranah fisik dan abstrak selalu hadir dalam desain arsitektur vernakular walaupun dengan bobot yang berbeda. Jika salah satu tidak ada maka nilai vernakularitas menjadi tidak muncul (Mentayani et al., 2017).

\section{Peradaban Islam}

Peradaban Islam dimulai sejak zaman Rasulullah saw hingga saat ini. Menurut Nourouzzaman Shiddiqy, sejarah peradaban Islam dibagi menjadi 3 periode yaitu klasik, pertengahan, dan modern. Periode klasik dimulai sekitar tahun $650 \mathrm{M}$ hingga $1258 \mathrm{M}$ yang ditandai dengan jatuhnya Bagdad ke tangan Hulagu Khan. Periode pertengahan dimulai tahun 1258 hingga akhir abad ke-17. Periode Modern dimulai abad ke-18 sampai sekarang ini. Pada periode klasik merupakan 
masa kemajuan Islam, dan Peradaban Islam masih terpusat di Arab. Pada periode pertengahan dan Modern, peradaban Islam sudah menjangkau wilayah yang lebih luas sehingga ada peradaban dan kebudayaan non Arab. (Nasution, 2013).

Peradaban Islam dimulai sejak masa Rasulullah Muhammad SAW, yang dilanjutkan dengan masa khulafaurrasyidin sesudahnya. Namun pada masa Rasulullah dan Khulafaurrasyidin tidak banyak ditemukan peninggalan arsitektur. Salah satu peninggalan yang bisa ditemukan hingga sekarang adalah bangunan peribadatan yaitu Masjid.

Terdapat beberapa masjid bersejarah di Makah dan Madinah yang masih ada hingga sekarang ini. Masjid Jin, merupakan masjid bersejarah di Makah yang sering disebut juga masjid Al Bai'ah karena terkait dengan peristiwa berbaiatnya Jin untuk beriman kepada Allah SWT. Peristiwa ini diabadikan pada QS Al Ahqaf 29-32. Selain masjid AI Jin, ada juga masjid Qiblatain di Madinah yang bersejarah karena menjadi tempat dimana turun ayat perpindahan arah kiblat umat Islam dari Masjidil Aqsa ke arah Ka'bah di Masjidil Haram. Hal ini diabadikan pada QS Al Baqarah ayat 144 (Ashadi, 2018).

Pada masa khulafaurrasyidin, perluasan wilayah Islam menjangkau hingga ke berbagai arah. Misalnya pada masa Khalifah Umar Bin Khottob, Islam sampai ke seluruh jazirah Arabia, Palestina, Syiria, sebagian besar Persia dan Mesir. (Nasution, 2013)

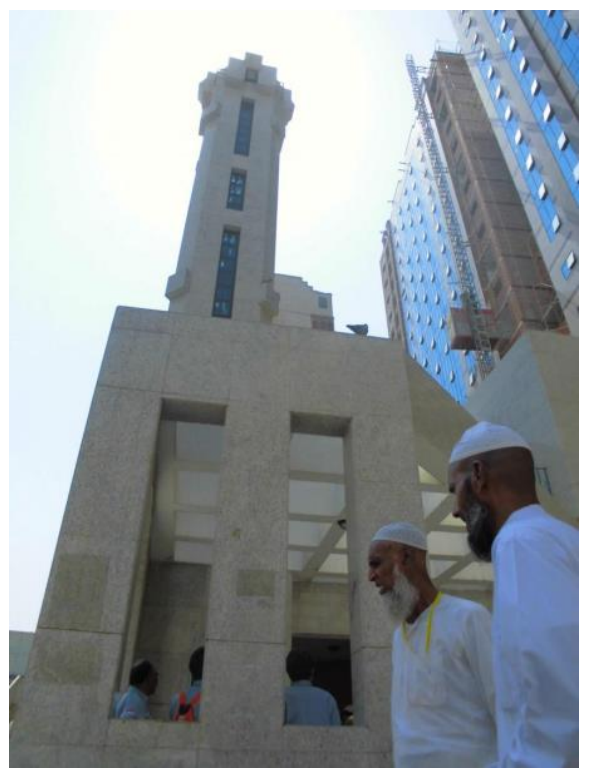

Gambar 1. Masjid Jin (Sumber : Nashrullah, 2020)

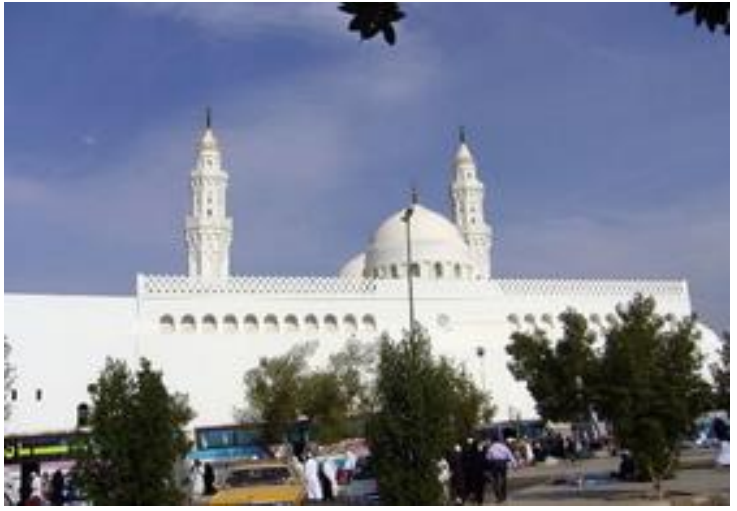

Gambar 2. Masjid Qiblatain

(Sumber : Anonim, 2015)

\section{Kondisi Iklim dan Geografis Afrika}

Benua Afrika merupakan benua yang sangat luas serta merupakan padang pasir terluas di dunia. Padang pasir membentang $1600 \mathrm{~km}$ dari utara hingga selatan dan membentang lebih dari $4800 \mathrm{~km}$ dari timur ke barat (Sumalyo, 2006).

Iklim di benua Afrika terbagi menjadi 5 yaitu : (1) Daerah iklim sedang/subtropics, pantai tenggara Afrika Selatan, wilayah selatan, dan garis balik selatan; (2) Daerah iklim tropis, daerah di sekitar equator yaitu sepanjang pantai Afrika Barat, Kenya, Uganda dan sebagian pantai di wilayah timur; (3) Daerah iklim gurun, terdapat di Afrika bagian utara dan barat daya' (4) Daerah iklim mediterania, terdapat di wilayah paling utara Afrika di sekitar Laut Tengah; (5) Daerah iklim pegunungan, terdapat di wilayah pegunungan (Anonim, 2021).

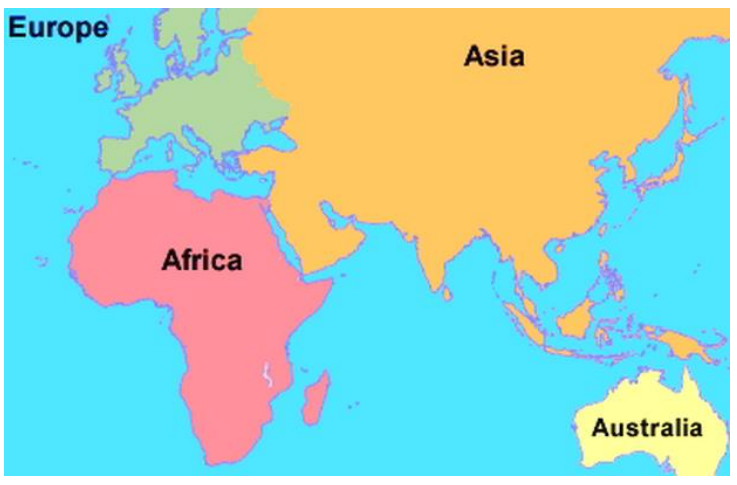

Gambar 3. Letak Benua Afrika

(Sumber : Anonim. 2018)

Berdasarkan penjelasan diatas maka Afrika Barat sebagian beriklim tropis. Sedangkan pada bagian barat daya beriklim gurun. 
Afrika barat saat ini meliputi 14 negara yaitu Mali, Burkina, Niger, Pantai Gading, Guinea, Senegal, Mauritania, Benin, Togo, Kamerum, Guinea-Bissau, Sao Tome dan Principe, Guinea Ekuatorial, Sahara Barat, Liberaia, Sierra Leone, Gambia, Ghana dan Nigeria (Supriyadi, 2020).

\section{Bentuk Massa dan Denah Bangunan}

Vernakularitas bangunan dapat dilihat dari 3 aspek yaitu aspek teknis, aspek budaya, dan aspek lingkungan. Ketiga aspek ini nanti akan dibahas secara bersama karena adanya saling keterkaitan diantara ketiganya. Secara arsitektural, vernakularitas dapat mulai dilihat dengan mengamati bentuk bangunan. Dari bentuk bangunan, kemudian akan dilanjutkan ada struktur konstruksi dan material, serta kaitannya dengan lingkungan termasuk di dalamnya iklim.

Peninggalan Peradaban Islam yang ada di Afrika, terutama Afrika Barat beberapa masih dapat dilihat hingga sekarang. Kebanyakan peninggalan tersebut berupa bangunan peribadatan yaitu masjid. Peninggalan peradaban Islam berkaitan dengan Kerajaan yang dahulu ada di tempat tersebut, antara lain Kerajaan Mali. Mansa Musa membawa Kerajaan Mali menuju kejayaan pada tahun 1312-1337 dan dilanjutkan pada masa Mansa Sulayman (1340-1360), hingga berhasil memperluas wilayah kekuasaan Islam ke wilayah Savanna dengan pusat penyebaran pada Djenne dan Timbuktu (Sumalyo, 2006).

Bentuk masjid yang menjadi peninggalan arsitektural sangat khas dan berbeda dengan tipologi masjid di Arab dan wilayah penyebaran Islam lainnya. Bentuk masjid sangat unik terutama pada bagian bentuk massa dan tampak bangunannya. Bentuk massa bangunan masjid semakin keatas semakin mengecil. Dari luar terlihat bangunan ini masif, tidak banyak bukaan. Selain itu dari luar terlihat ada batang pohon/kayu yang menonjol.

Dari bentuk denah, bangunan masjid ini berdenah persegi. Walaupun tidak selalu menggunakan pola hypostyle sebagai pola tipologi masjid pada umumnya. Pada masjid DjinguereBer yang ada di Timbuktu, bentuk massa dari luar tampak persegi namun dari dalam tidak menggunakan pola hypostyle. Masjid ini mempunyai halaman dalam namun tidak dapat disebut sahn karena tidak ada iwan yang mengelilinginya.
Pada pola hypostyle, sahn (halaman dalam) dikeliling oleh 4 iwan, salah satunya haram yaitu sebagai tempat sholat utama.

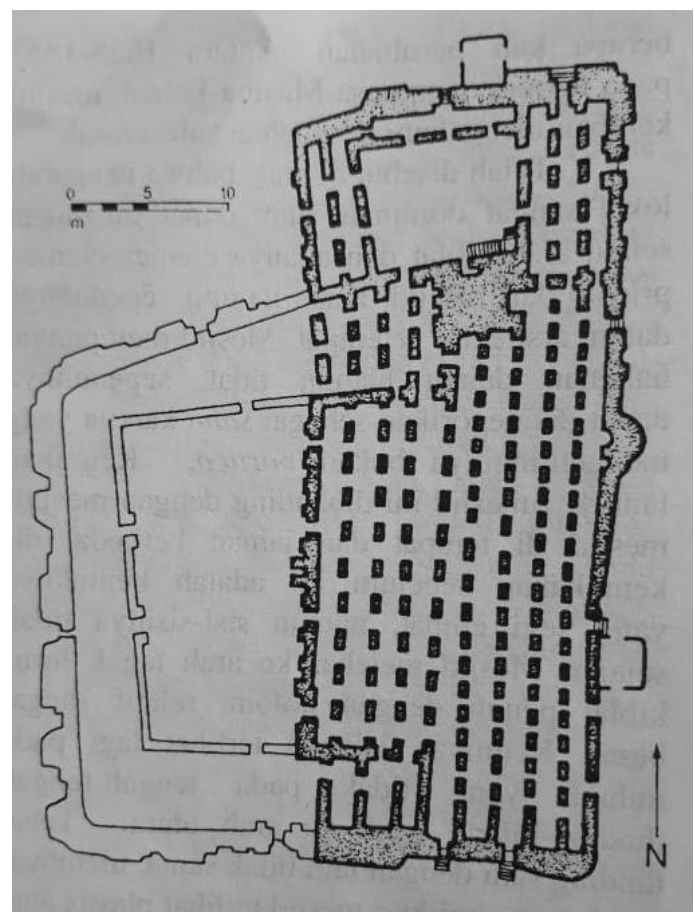

Gambar 4. Denah masjid Djinguereber (Sumber : Sumalyo, 2006)

Masjid DjinguereBer ini merupakan Masjid yang dibangun sesudah Mansa Musa menunaikan ibadah haji. Saat ini masjid sudah mengalami beberapa kali renovasi sehingga sudah mengalami perubahan walau bukan pada bagian intinya. Vernakularitas masih dapat dilihat walau sudah mengalami perubahan.

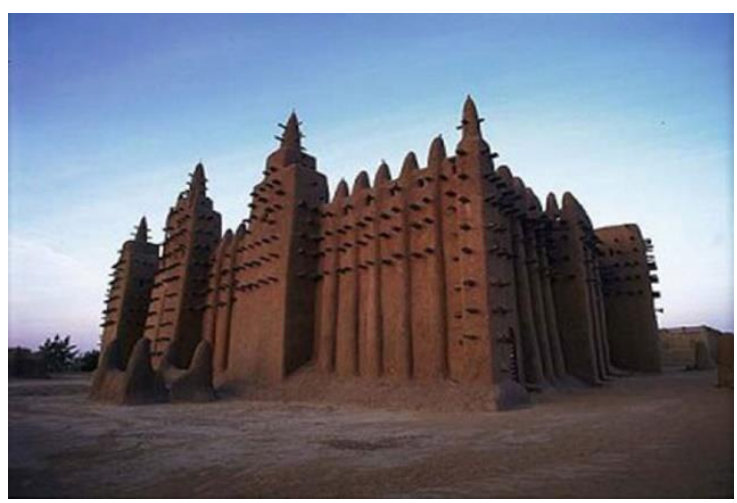

Gambar 5. Masjid DjinguereBer

(Sumber : Sasongko, 2015)

Masjid Sankore yang ada di Timbuktu mempunyai kemiripan dengan Masjid DjinguereBer dalam bentuk, konstruksi dan material. Bentuknya persegi, dengan konstruksi bata dari tanah liat dan diberi 
perkuatan batang kayu. Denah masjid Sankore ini hypostyle dengan sahn berada di tengah bangunan masjid.

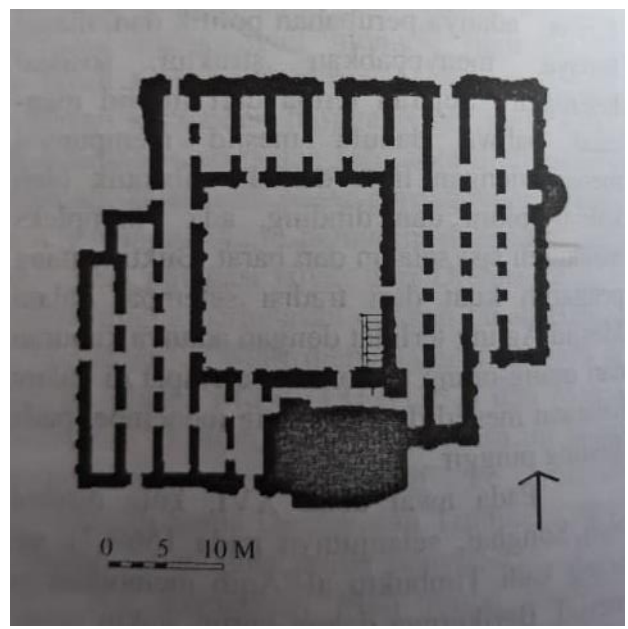

Gambar 6. Denah Masjid Sankore (Sumber : Sumalyo, 2006)

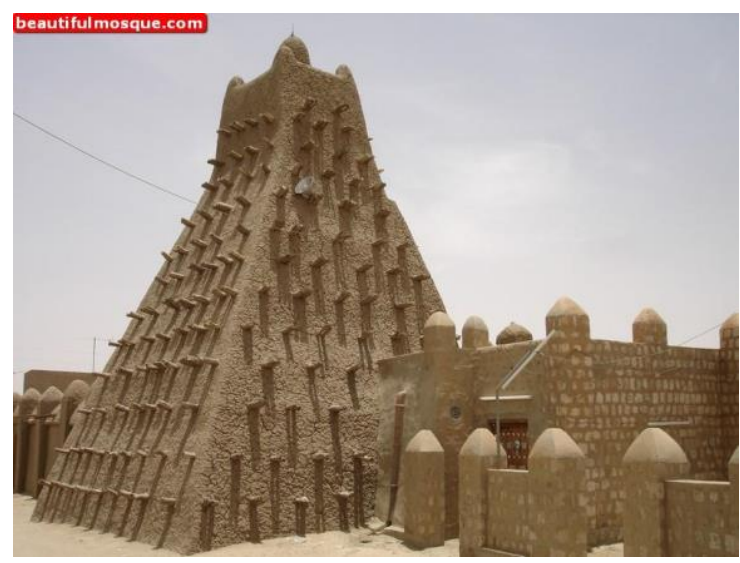

Gambar 7. . Masjid Sankore (Anonim. TT)

Peninggalan peradaban Islam lainnya adalah Masjid Agung Djenne, secara arsitektural mempunyai kemiripan dengan Masjid DjinguereBer dan Sankore. Bentuk massa persegi, terkesan masif dan minim bukaan. Ada yang berbeda dari segi denah, pada masjid Agung Djenne persegi atau segi empat namun tidak teratur.

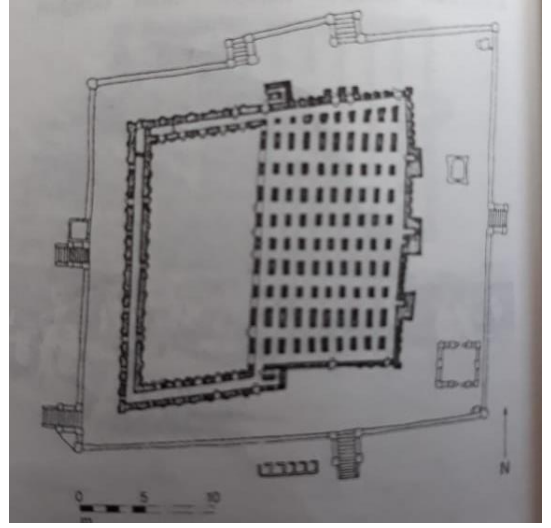

Gambar 8. Denah Masjid Agung Djenne (Sumber : Sumalyo, 2006)

Ada yang mengatakan denah masjid ini lebih mendekati bentuk jajaran genjang daripada segi empat. Masjid ini berdiri diatas platform, secara arsitektural seperti dasar untuk membuat bangunan terlihat lebih tinggi. Denah bangunan hypostyle, dengan sahn ditengah yang dikelilingi oleh iwan dan salah satunya haram sebagai tempat sholat utama dan tempat arah kiblat.

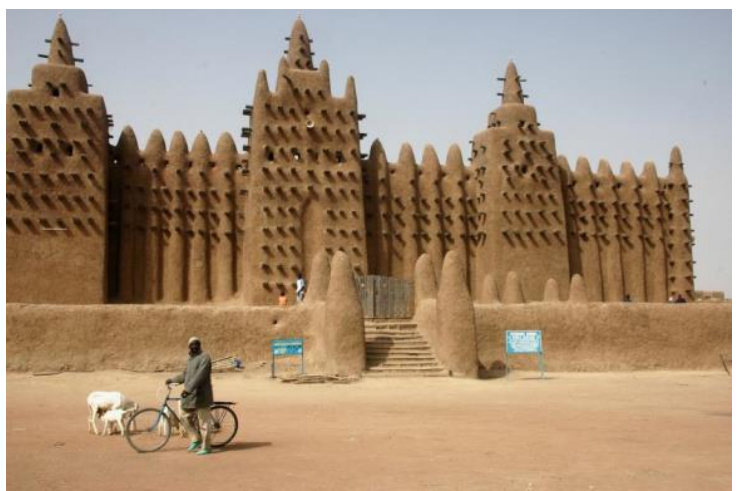

Gambar 9. Masjid Agung Djenne

(Sumber : Nursalikah, 2021)

Selain peninggalan peradaban Islam di Timbuktu dan Djenne, ada masjid Agung Mopti yang dapat ditelusuri secara arsitektural. Masjid ini terletak di Kota Mopti yang berada di tepi Sungai Niger. Masjid ini dibangun pada masa yang sama dengan Masjid Agung Djenne. Namun dari denah masjid ini tidak sama dengan masjid Agung Djenne. Denah Masjid Mopti tidak mengikuti hypostyle, karena tidak mempunyai sahn. Namun secara bentuk luar dan struktur konstruksi serta materialnya sama dengan Masjid Agung Djenne. Masjid ini berdiri diatas platform, seperti halnya masjd Agung Djenne namun platform tidak sejajar dengan denahnya. 
Berdasarkan amatan terhadap literatur empat Masjid yang ada di Afrika Barat dapat dipaparkan bahwa dari bentuk massa peninggalan peradaban Islam yang ada di Afrika Barat pada bangunan masjid terdapat kesamaan dan karakteristik khas. Karakteristik khas bentuk massa masjid berkaitan dengan kondisi lingkungannya, yaitu berada di antara tropis dan gurun.

Bentuk massa persegi, dengan tampak bangunan yang mirip yaitu menjulang ke atas namun tidak terlalu tinggi. Dari luar terlihat masjid ini masif, bahkan minaretnya pun terlihat masif. Pada bangunan masjid, bukaan pintu jendela sedikit, dikaitkan dengan kondisi iklim yang panas di luar bangunan.

Vernakularitas dari bentuk massa bangunan masjid di Afrika Barat ini terlihat jelas dan berbeda dengan peninggalan peradaban Islam diwilayah lain. Pengaruh dari arsitektur setempat terlihat jelas pada bagian tampak bangunan, dengan bahan bata tanah liat dan diberi penguat dan elemen estetika berupa batang kayu.

Denah bangunan peninggalan peradaban Islam di Afrika Barat tidak selalu menggunakan pola hypostyle. Pola hypostyle ini merupakan pola denah yang banyak digunakan pada peninggalan peradaban Islam. Pada pola hypostyle, dengan bentuk massa persegi, dilengkapi Sahn pada bagian tengan dan iwan pada keempat sisinya. Iwan ini yang secara arsitektural mirip dengan portico. Iwan pada bagian kiblat digunakan sebagai tempat sholat utama dan disebut dengan haram. Pola hypostyle ini ternyata tidak selalu diaplikasikan pada peninggalan peradaban Islam di Afrika Barat.

\section{Struktur konstruksi dan Material}

Bentuk bangunan yang khas pada peninggalan peradaban Islam di Afrika Barat berkaitan dengan lokalitas. Penggunaan material lokal yang didukung dengan teknologi membangun dan pemeliharaan lokal membuat vernakularitas bangunan ini mudah dilihat.

Material yang digunakan pada masjid dan juga rumah-rumah adalah bata yang berasal dari tanah liat yang dikeringkan. Untuk memperhalus permukaan dinding maka dilakukan plester menggunakan tanah liat. Sebagai perkuatan dinding bata tanah liat tersebut, ditancapkan batang kayu yang tegak lurus dari permukaan dinding. Batang kayu ini selain berfungsi sebagai penguat, juga dapat digunakan secara estetika untuk memperindah bangunan. Batang kayu ini juga fungsional dapat digunakan sebagai pijakan ketika melakukan upaya pemeliharaan bangunan yaitu memplester ulang terutama bagian luar bangunan.

Material tanah liat yang dikombinasikan bentuk massa persegi relative masif, sangat sesuai dengan iklim di Afrika Barat. Bahan bata ini dapat mendinginkan ruang yang ada di dalamnya.

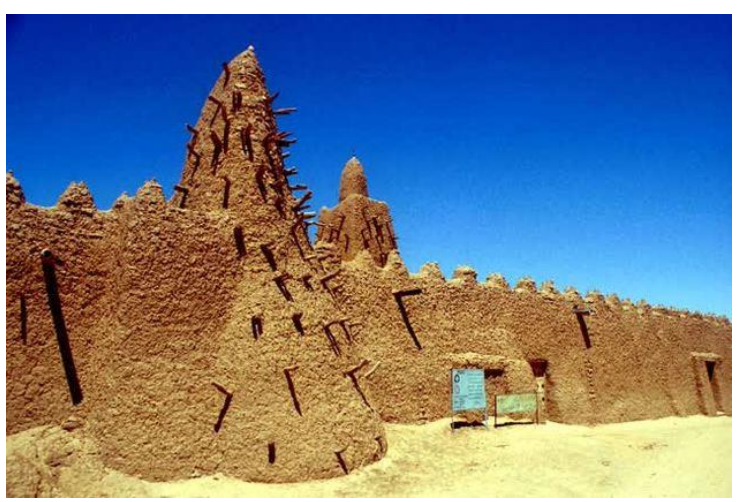

Gambar 10. Dinding Masjid DjinguereBer (Sumber : archnet.org)

Material susunan bata berasal dari tanah liat yang dikeringkan dapat ditemukan pada masjid DjinguereBer. Berbeda dengan bata yang biasa digunakan sebagai material yang berasal dari tanah liat-dicetak-cibakar. Kebanyakan peninggalan peradaban Islam di Afrika Barat menggunakan tanah liat dikeringkan tanpa dibakar. Karena berasal dari bahan alam, maka ketika dinding terutama bagian luar terpapar panas maka diperlukan pemeliharaan. Pemeliharaan yang dilakukan adalah dengan melapisi dinding menggunakan tanah liat.

Sumalyo (2006) menjelaskan bahwa selain digunakan untuk memperkuat dan pijakan ketika dilakukan pemlesteran ulang, batang kayu tersebut juga difungsikan sebagai penahan gaya tarik.

Dinding dari tanah liat tersebut tidak bisa $100 \%$ rata antara lain disebabkan sifat bahan alami dan plastis. Hal ini dapat dilihat pada Masjid Sankore dan masjid Agung DinguereBer serta masjid Agung Djenne. 


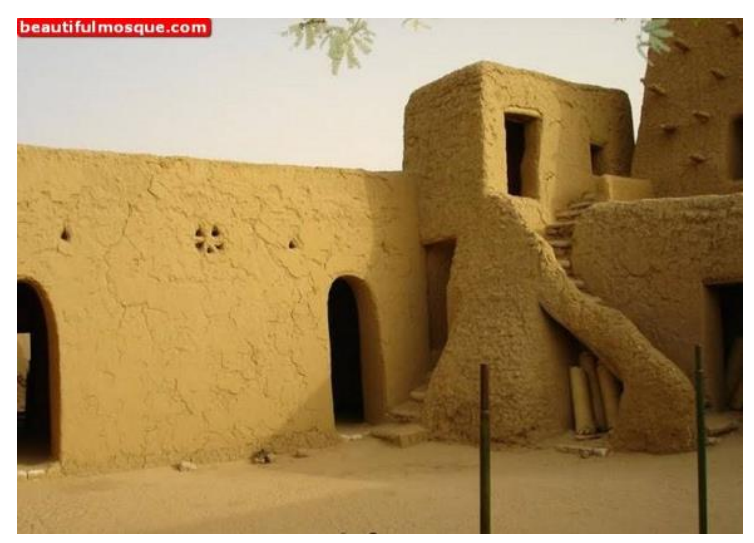

Gambar 11. Material Lumpur pada Masjid Sankore (Sumber :Anonim, tt)

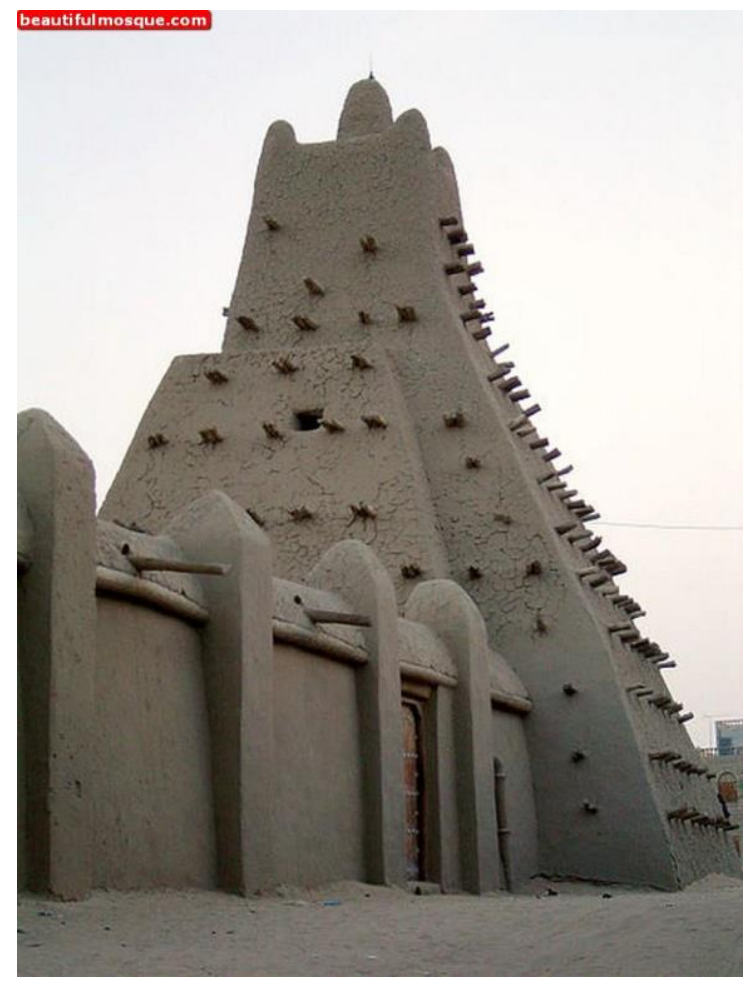

Gambar 12. Kayu sebagai Penguat pada Masjid Sankore

(Sumber : Anonim, tt)

Pada masjid Agung Djenne terdapat konstruksi penguat seperti pilaster. Konstuksi penguat tersebut menonjol keluar dan terlihat tidak rata dengan dinding di sekitarnya. Penguat bagian dinding ini juga ditemukan pada masjid Mopti. Pada beberapa bagian dinding yang diperkuat, kemudian menjulang hingga keatas dan berbentuk runcing.

Minaret juga dibuat dengan bahan yang sama dengan masjidnya. Karena bahan tanah liat inilah maka minaretnya tidak menjulang tinggi. Tangga minaret ada yang di dalam maupun diluar. Pada minaret dengan tangga diluar maka minaretnya masif tanpa lubang ditengah, seperti pada masjid Sankore. Sedangkan pada masjid Agung Djenne, tangga minaret diletakkan di dalam. Minaret tidak menjadi kelengkapan dari bangunan masjid di Afrika barat.

Karena perkuatan pada bangunan terletak pada dinding maka dapat dilihat dindingnya tebal. Bahkan pada masjid Agung Djenne kolomnya sangat tebal dan panjang seperti dinding. Hal ini merupakan bukti vernakularitas peninggalan peradaban islam di Afrika barat yang menggunakan material lokal dan stryktur konstruksi lokal.

Lokalitas ini tidak mengurangi fungsi masjid itu sendiri. Masjid masih dapat digunakan secara fungsional dengan material lokal dan teknologi lokal.

\section{Penafsiran Vernakularitas}

Penelitian mengenai vernakularitas peninggalan peradaban Islam ini dilakukan di beberapa tempat untuk melihat lokalitas bangunan dari tempat masing-masing. Salah satu tempat yang diteliti adalan Afrika Barat yang dipaparkan dalam makalah ini. Tujuan penelitian ini adalah untuk mengidentifikasi, mendeskripsikan dan memahami vernakularitas arsitektur peninggalan peradaban Islam di Afrika Barat.

Penafsiran ini dilakukan sebagai tahap akhir penelitian vernakularitas arsitektur peninggalan peradaban Islam di Afrika Barat secara khusus. Dalam pengambilan data dan analisis dirujuk pendapat Mentayani berkaitan dengan aspek-aspek vernakularitas.

Telah dibahas dibagian awal analisis, identifikasi dan deskripsi berkaitan dengan aspek fisik-budaya-lingkungan untuk melihat vernakularitas dengan menekankan pokok bahasan pada 2 hal. Pertama, bentuk massa dan denah bangunan. Kedua, struktur konstruksi dan material.

Empat buah masjid yang merupakan peninggalan peradaban Islam di Afrika Barat digunakan sebagai studi kasus terpilih untuk melihat vernakularitas.

Penafsiran merujuk pada (Mentayani, et al, 2017) yang menyebutkan bahwa Arsitektur vernakular juga dapat diungkapkan sebagai kesatuan antara bentukan fisik dan kandungan makna abstrak yang terwujud melalui teknis, 
dilandasi budaya dan dipengaruhi oleh lingkungan.

Vernakularitas arsitektur peninggalan peradaban Islam di Afrika barat tercipta karena adanya adaptasi antara bentuk dengan kondisi setempat. Secara bentuk tetap fungsional, namun secara arsitektural sesuai dengan kebutuhan setempat;

Material, proses pembangunan dan bentuk yang tercipta muncul didasarkan adanya sumberdaya, teknologi, danmaterial setempat; Bangunan ini dibangun untuk mewadahi aktivitas khusus dalam hal ini peribadatan. Sesuai dengan masuk dan meluasnya Islam pada wilayah tersebut. Masjid sebagai peninggalan peradaban Islam ada karena kebutuhan masyarakat untuk mewadahi aktivitas peribadatan.

Peninggalan peradaban Islam di satu wilayah dengan wilayah lain memiliki bentuk yang khas dan spesifik. Hal ini disebabkan karena peninggalan peradaban Islam dipengaruhi kondisi setempat. Peninggalan di Afrika Barat, dipengaruhi arsitektur tropis-gurun, baik pada bentuk bangunan maupun pada material yang digunakan.

\section{KESIMPULAN}

Kesimpulan penelitian Vernakularitas Arsitektur Peninggalan Peradaban Islam di Afrika Barat adalah :

1. Arsitektur peninggalan peradaban Islam dibawa oleh para penyebar agama Islam sebelum mengalami percampuran dengan budaya lokal, termasuk iklim setempat. Arsitektur peradaban Islam di Afrika Barat khususnya dibawa oleh penyebar agama Islam dan dari umat muslim yang menjalankan ibadah haji. Karena itulah dari segi bentuk massa, tidak selalu mengikuti bentuk hypostyle. Dari segi ornemen juga tidak menggunakan bentuk geometris, intricate, maupun muqornas seperti halnya peninggalan peradaban Islam yang mendapat pengaruh dari Persia maupun yang ada di wilayah Bumi Syam.

2. Vernakularitas arsitektur peninggalan peradaban Islam di Afrika Barat dapat dilihat pada bentuk massa dan denah bangunan, yang tetap fungsional untuk beribadah dan beraktivitas umat Islam namun dikaitkan dengan kondisi setempat. Bentuk persegi, masif, tidak banyak bukaan merupakan solusi terhadap iklim Afrika Barat. Hal ini didukung dengan material dan struktur konstruksi khas Afrika yang menggunakan batu bata dari tanah liat dikeringkan tanpa dibakar. Material ini diperkuat dengan batang kayu uang berfungsi sebagai penguat dan bernilai estetika. Estetika secara vernakular dapat tercipta dari bentuk bangunan dan elemen penguat yang menempel pada dinding terluar.

\section{DAFTAR PUSTAKA}

Anisa, \& Nur'aini, R. D. (2020). Kajian Aspek Vernakularitas Pada Rumah Kilungan Di Kota Lama Kudus. NALARs, 19(2), 105. https://doi.org/10.24853/nalars.19.2.105114

Anonim. (2021). Karakteristik Benua Afrika. Retrieved July 13, 2021, from https://www.dosenpendidikan.co.id/kara kteristik-benua-afrika

Artiningrum, P., \& Sukmajati, D. (2017). Adaptasi Arsitektur Vernakular Kampung Nelayan Bugis Di Kamal Muara. NALARs, $\quad 16(1)$, 69-84. https://doi.org/10.24853/nalars.16.1.6984

Ashadi. (2018). Kelengkapan Peradaban dan Arsitektur Islam Zaman Kenabian. Jakarta: Arsitektur UMJ Press.

Mentayani, I. ... Muthia, P. R. (2017). Menggali Makna Arsitektur Vernakular: Ranah, Unsur, dan Aspek-Aspek Vernakularitas. Prosiding Temu IImiah IPLBI, I109-I116. https://doi.org/10.32315/ti.6.i109

Rengkung, J. (2011). Arsitektur Vernakular Rumah Tinggal Masyarakat Etnik Minahasa. Media Matrasain, 8(3), 108120.

Sani, A. A. ... Rukayah, R. S. (2015). Bentuk Dan Proporsi Pada Perwujudan Arsitektur Vernakular Bugis. Jurnal Teknik Sipil Dan Perencanaan, 17(2), 99-110.

https://doi.org/10.15294/jtsp.v17i2.6885

Saraswati, T. (2008). Vernakularitas Los, Bangunan Pengering Tembakau Di Kabupaten Klaten, Jawa Tengah. DIMENSI (Jurnal Teknik Arsitektur), 36(1), 65-74. Retrieved from http://puslit2.petra.ac.id/ejournal/index.ph p/ars/article/view/16975

Sinaga, G. S. (2017). Ekspresi Vernakular Minangkabau pada Masjid Raya Gantiang. Seminar IPLBI 1, A133-A138. https://doi.org/10.32315/sem.1.a133

Sumalyo, Y. (2006). Arsitektur Mesjid dan Monumen Sejarah Muslim. Yogyakarta: Gadjah Mada University Press.

Sumintardja, D. (1981). Kompendium Sejarah 
Arsitektur. Bandung: Penerbit Yayasan Lembaga Penyelidikan Masalah Bangunan.

Supriyadi. (2020). Afrika Barat terbagi menjadi 14 Negara. Retrieved July 13, 2021, from https://www.sejarahnegara.com/69160/afrika-barat

Tarigan, R. (2016). Arsitektur Vernakular Berbasis Arsitektur Tradisional: Menuju Arsitektur Lokal Yang Berkelanjutan. Tesa Arsitektur, 14(1), 23-32.

Wulandari, C. ... Topan, M. A. (2018). Kajian Terhadap Ekspresi Bentuk Arsitektur Vernakular Bengkulu Masjid Agung di Provinsi Bengkulu. Seminar Nasional Cendikiawan Ke 4, 159-164.

Nasution, Syamrudin. (2013). Sejarah Peradaban Islam. Yayasan Pustaka Riau.

Sumber gambar

Nashrullah, Nashih. (2020). Masjid Jin, Lokasi Rasulullah SAW Baiat Delegasi Bangsa Jin. https://republika.co.id/berita/q847v1320/masj id-in-lokasi-rasulullah-saw-baiat-delegasibangsa-iin

Anonim. (2015). Masjid Qiblatain, Saksi Perpindahan Kiblat.

https://kemenag.go.id/read/masjid-qiblatain-saksiperpindahan-kiblat-6wjvj

Anonim. (2018). Letak Astronomis, Geografis dan Geologis Benua Afrika serta Keuntungan

https://www.geologinesia.com/2018/10/l etak-astronomis-geografis-dan-geologisbenua-afrika.html

Sasongko, Agung. (2015). di Muslim, Penguasa Djenne Ubah Istana Jadi Masjid https://www.republika.co.id/berita/nu1pri 313/jadi-muslim-penguasa-djenne-ubahistana-jadi-masjid

Anonim. Tanpa tahun. sankore mosque in timbuktu -mali https://www.beautifulmosque.com/sanko re-mosque-in-timbuktu-mali

Nursalikah. Ani (2021). asjid Agung Djenne, Megah Berbahan Lumpur di Mali https://republika.co.id/berita/qxidvg366/ masjid-agung-djenne-megah-berbahan$\underline{\text { lumpur-di-mali }}$ 